\section{Packout Audits of Apples from Five Orchard Management Systems}

\author{
T. Auxt Baugher',
}

H.W. Hogmire',

A.R. Biggs', G.W. Lightner ${ }^{2}$,

S.I. Walter ${ }^{1}$ D.W. Leach ${ }^{1}$, and T. Winfield ${ }^{1}$

Additional index words. packout losses, training systems, Malus domestica, production efficiency, light quality

Summary. Apple packout audits were conducted during 1991 to 1993 to assess effects of five orchard systems (three cultivars, two age groups) on fruit packout and determine if relationships exist between light quality and productivity. Cultivar/ rootstock combinations on $1979 \mathrm{~T}$ trellis and central-leader systems had the lowest light levels and relative yields. Trees on either 1979 3-wire trellis, 1986 MIA, or 1985 West Virginia spindle had the highest light transmission, and trees on 1979 or 1985 West Virginia spindle systems had the highest yields. Extra fancy/ fancy packouts across systems ranged from $40 \%$ to $85 \%$. 'Empire', regardless of system, had the highest packouts, and 'Golden Delicious' on 1979 or 1986 central leader had the lowest packouts. A regression analysis comparing percentage packout in grades below fancy to percentage full sun indicated that reduced packouts were related to low light conditions. Orchard system influenced the number of fruit downgraded due to color, russet, bruises, bitter pit, cork spot, apple scab, rots, sooty blotch/

${ }^{1}$ West Virginia University Experiment Farm, P.O. Box 609, Kearneysville, WV 25430

${ }^{2}$ USDA-ARS Appalachian Fruit Research Station, 45 Wiltshire Rd., Kearneysville, WV 25430.

Approved for publication by the director, West Virginia Agriculture and Forestry Experiment Station, as scientific article no. 2511. The cost of publishing this paper was defrayed in part by the payment of page charges. Under postal regulations, this paper therefore must be hereby marked advertisement solely to indicate this fact. fly speck, and tufted apple budmoth. Regression analyses comparing defects to field data indicated that bitter pit decreased as yield efficiency increased, and rot and sooty blotch/fly speck incidence were related to low canopy light penetration. Revenue losses were disproportionate to percentage of downgraded fruit because some defects had a greater impact on grade than others. The greatest revenue losses were for russet in 'Golden Delicious' on 1986 central leader (\$1656.60/acre) and for bitter pit in 'Golden Delicious' on 1979 T-trellis (\$1067.30/acre). Total losses in returns for individual systems ranged from \$453.71/acre for 'Empire' on 3wire trellis to $\$ 3145.49$ /acre for 'Golden Delicious' on 1986 central leader. The comparisons of young versus mature system yields and packouts indicate that medium- to high-density vertical or inclined canopy systems are superior to horizontal or low-density vertical freestanding systems. The cost-benefit analyses prescribe areas where management can be changed in existing systems to increase profitability.

$\mathrm{I}$ ntensive orchard planting systems offer growers the opportunity to reduce or change labor requirements, increase rate of return on investment, increase marketing flexibility, reduce environmental impacts, and improve fruit quality. Economic comparisons of high-density apple production systems have dealt extensively with labor, investment, and marketing factors, but fruit packout differences have been more difficult to assess (Blizzard et al., 1988; Ferree, 1989; Hogmire and Biggs, 1990; Robinson et al., 1991).

Russo and Rajotte (1983) developed a theoretical grading scheme, that arrayed USDA grades for apples in a chart format to help quantify the impact of defects on packout. The authors modified the chart in a previously reported study (Hogmire et al., 1989) so that the cause of a defect and the loss of revenue due to the defect also could be determined. We simultaneously developed a submersion-tank sampling technique for predicting packout to within $10 \%$ and defects to within 5\% (Baugher et al., 1990a, 1990e; Hogmire et al., 1989).

The West Virginia Univ. Experiment Farm (WVUEF), Kearneysville, WVa., is the site of a collection of 
intensive orchard planting systems of three cultivars in two age groups. The trees in the older of the two age groups are unique in that they have been established longer than trees in many previously reported comparisons of orchard systems. Apple packout audits were conducted during 1991 to 1993 to assess effects of orchard systems on fruit packout and determine if relationships exist between light quality and productivity.

\section{Materials and methods}

Intensive orchard planting systems were established at the WVUEF in 1979 and 1985-86. Low-density freestanding systems were planted in the same years. The systems, cultivars, rootstock, tree spacings, and tree densities selected for this study are listed in Table 1. Trellis designs and tree training techniques are described in WVU extension publications (Baugher et al., 1990b, 1990c, 1990d; Elliott and Selders, 1990; Singha et al., 1990; Zimmerman et al., 1990). Row orientation in all systems was north-south. Current WVU extension pest control and cultural recommendations (Hogmire and Byers, 1990; Virginia and West Virginia Cooperative Extension Services, 1993 ) were followed in the plantings. Tree-row-volume pesticide rates of $50 \%$ were used in the systems with 202 or more trees per acre (499 trees per ha), and full rates were used on central-leader trees planted at densities of 100/acre (247/ha).

Light transmission and production efficiency were determined each season on 10 whole-tree replicates.
Light was measured in mid-August with a line quantum sensor light wand (LI-185B; LI-COR Lincoln, Neb.) held in a north-south orientation at the midsection of each tree canopy. Readings were taken between 1:00 to $1: 30$ PM on the east side of the trunk and were converted to percentages of full sun readings taken in row middles. Trunk diameters were measured in August-after terminal bud set-and were converted to trunk cross-sectional areas (TCSA). Apples were weighed at harvest (picks only, no drops), and production efficiencies $\left(\mathrm{g} \cdot \mathrm{cm}^{-2}\right.$ TCSA) were determined.

A Snedecor/Cochran sample size analysis (Snedecor and Cochran, 1968) was conducted to determine optimum sample size (95\% confidence level) for randomly collecting apples from the field for packout comparisons. We determined that, with 100 fruit samples from five of the 10 tree replicates, defects could be predicted to within $5 \%$ and packout to within $7 \%$. Five 100-fruit samples from each system were harvested and stored for 90 days in refrigerated storage. Fruit were inspected using techniques described by Hogmire et al. (1989), and packout audits were conducted using techniques described by Baugher et al. (1990e).

The experimental design was completely random. Data were analyzed using SAS's general linear models (GLM) procedure (SAS Institute, Cary, N.C.). Light transmission, yield efficiency, percentage of extra fancy/ fancy packout, percentage of apples with various defects, and loss of rev- enue due to defects were analyzed by analysis of variance, and means were separated by least significant differences. Regression analyses were performed on packout data to quantify relationships with horticultural parameters measured in the field.

\section{Results and discussion}

Light transmission production efficiency, and average yield Cultivar/rootstock combinations on 1979 T-trellis and 1979 central-leader systems had the lowest light levels and relative yields (Table 1). Trees on either 1979 3-wire trellis, 1986 MIA (system from Murrumbingee Irrigation Area, Australia) or 1985 WV spindle (West Virginia adaptation of spindle in which fewer training aides are used) had the highest light transmission, and trees on WV spindle systems had the highest yields and/or yield efficiencies.

'Empire', the most compact cultivar in the study, had the highest light transmission (Table 1), regardless of system. All trees on 3-wire trellis were in the highest light grouping, a finding consistent with reports by Ferree et al. (1989b) and Baugher et al. (1994). 'Golden Delicious' on MIA and WV spindle had full sun readings equal to 'Golden Delicious' on 3-wire trellis. Low light transmission in 1979 Ttrellis and 1979 central leader agree with earlier studies conducted at the WVUEF (Ferree et al., 1989b). Baugher et al. (1994) previously reported increased net photosynthesis in 'Golden Delicious' on 3-wire trellis compared to central leader.

Table 1. Comparisons of light transmission, production efficiency and average yield in five orchard systems during 1991 to 1993.

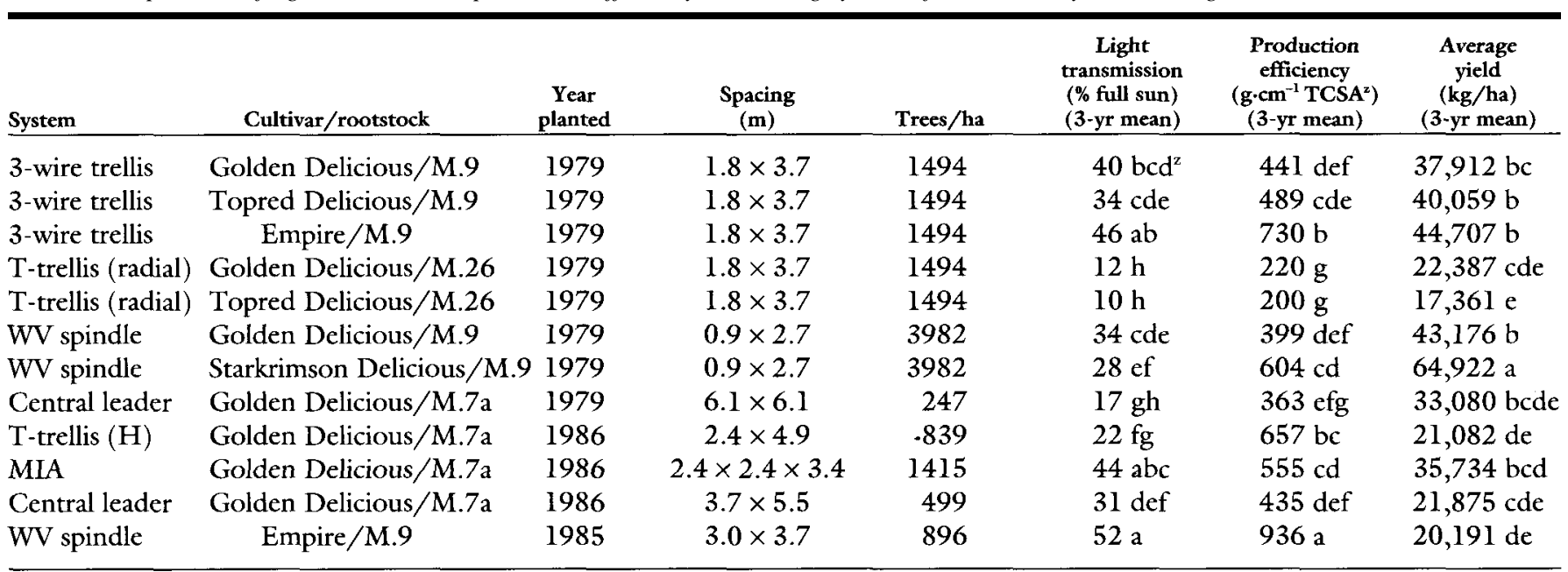

Means within columns followed by the same letter are not significantly different according to $L S D, \mathrm{P} \leq 0.05$. 


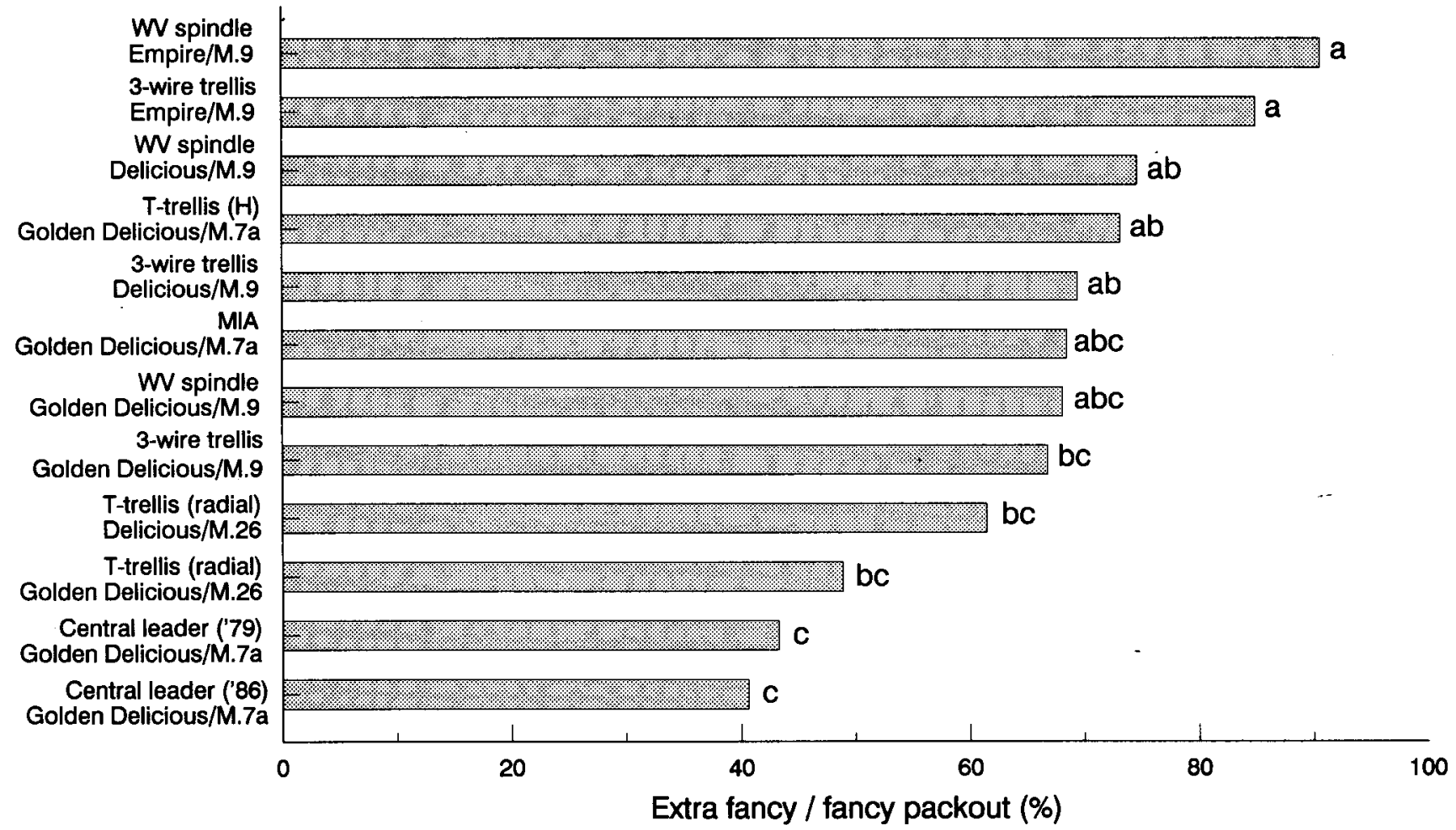

Fig. 1. Comparisons of average packouts in five orchard systems during 1991 to 1993. Means followed by the same letter are not significantly different according to LSD, $\mathrm{P}$ 0.05 .

'Empire' on WV spindle, 'Empire' on 3-wire trellis, and 'Golden Delicious' on 1986 T-trellis had the highest yield efficiencies, and 'Topred Delicious' and 'Golden Delicious' on 1979 T-trellis and 'Golden Delicious' on 1979 central leader had the lowest yield efficiencies (Table 1). 'Empire' had small TCSAs and consistently high annual yields. Blizzard et al. (1988) demonstrated that T-trellis yield efficiencies were similar to 3-wire trellis yield efficiencies in the first 4 years of production due to bending branches to a horizontal position. The current study, however, showed that T-trellis yield efficiencies were not sustained in the ninth to eleventh years of production, when shading increased due to high tree vigor.

'Starkrimson Delicious' on WV spindle had the highest 3-year average yields, and 'Empire' on 3-wire trellis, 'Golden Delicious' on WV spindle and 'Topred Delicious' on 3-wire trellis were in the next highest grouping (Table 1). 'Topred Delicious' on 1979 T-trellis had the lowest average yields. The data confirm previous reports by Robinson et al. (1991) and Ferree (1994) in which the slender spindle system out-produced the Y-trellis or central leader and the palmette leader or central leader, respectively.

Packout comparisons. Extra fancy/fancy packouts across systems for the 3-year period ranged from $40 \%$ to $90 \%$ (Fig. 1). 'Empire', regardless of system, had the highest packouts, and 'Golden Delicious' on either age of central leader had the lowest packouts. 'Delicious' on WV spindle or 3-wire trellis and 'Golden Delicious' on 1986 $\mathrm{T}$-trellis ( $\mathrm{H}$ training) had improved packouts compared to the same cult- vars on 1979 T-trellis (radial training) or 'Golden Delicious' on central leader, indicating that orchard system, in some years, may make the difference between sending a cultivar to a fresh-fruit packinghouse or a processing plant. Ferree et al. (1989a) previously reported no consistent effect of system on fruit downgrades due to size, but other packout determinants were not evaluated.

Fig. 2. Regression (significant at $\mathrm{P}$ 0.05) of packout below fancy vs. percentage of full sun in five orchard systems (1991 to 1993).

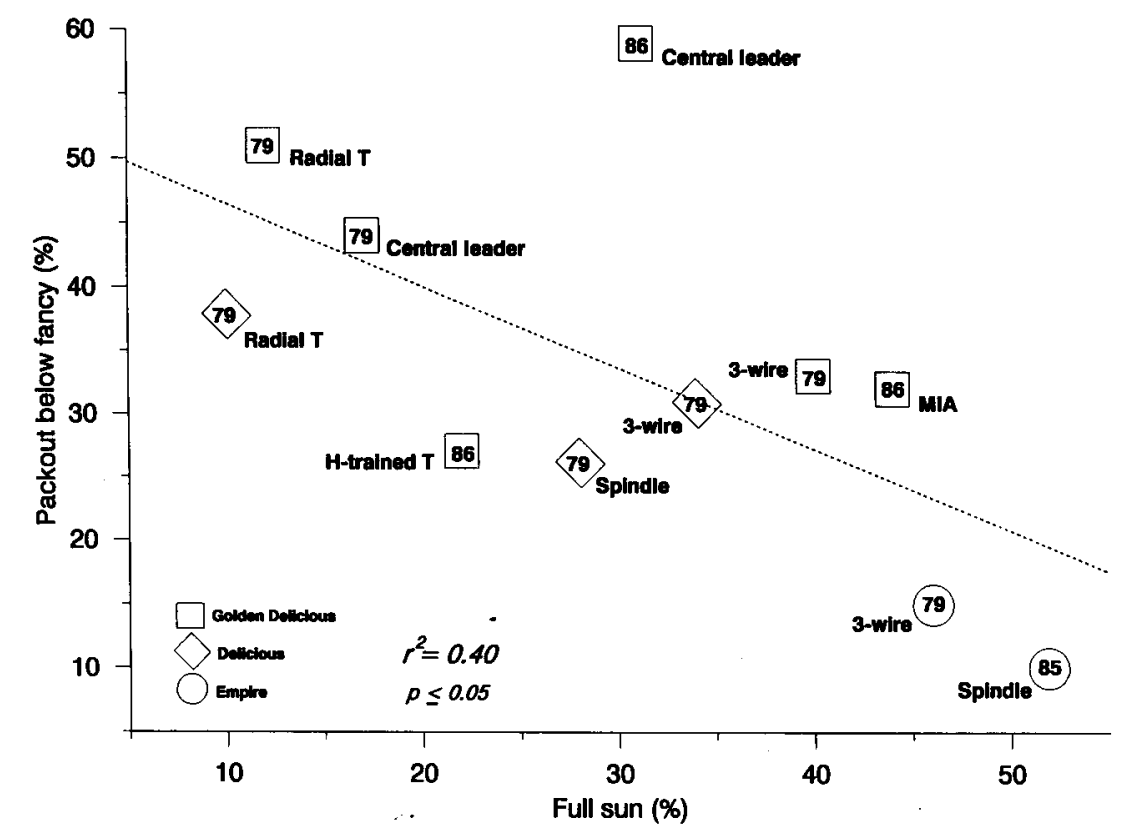


Table 2. Comparisons of defects in five orchard systems during 1991 to 1993.

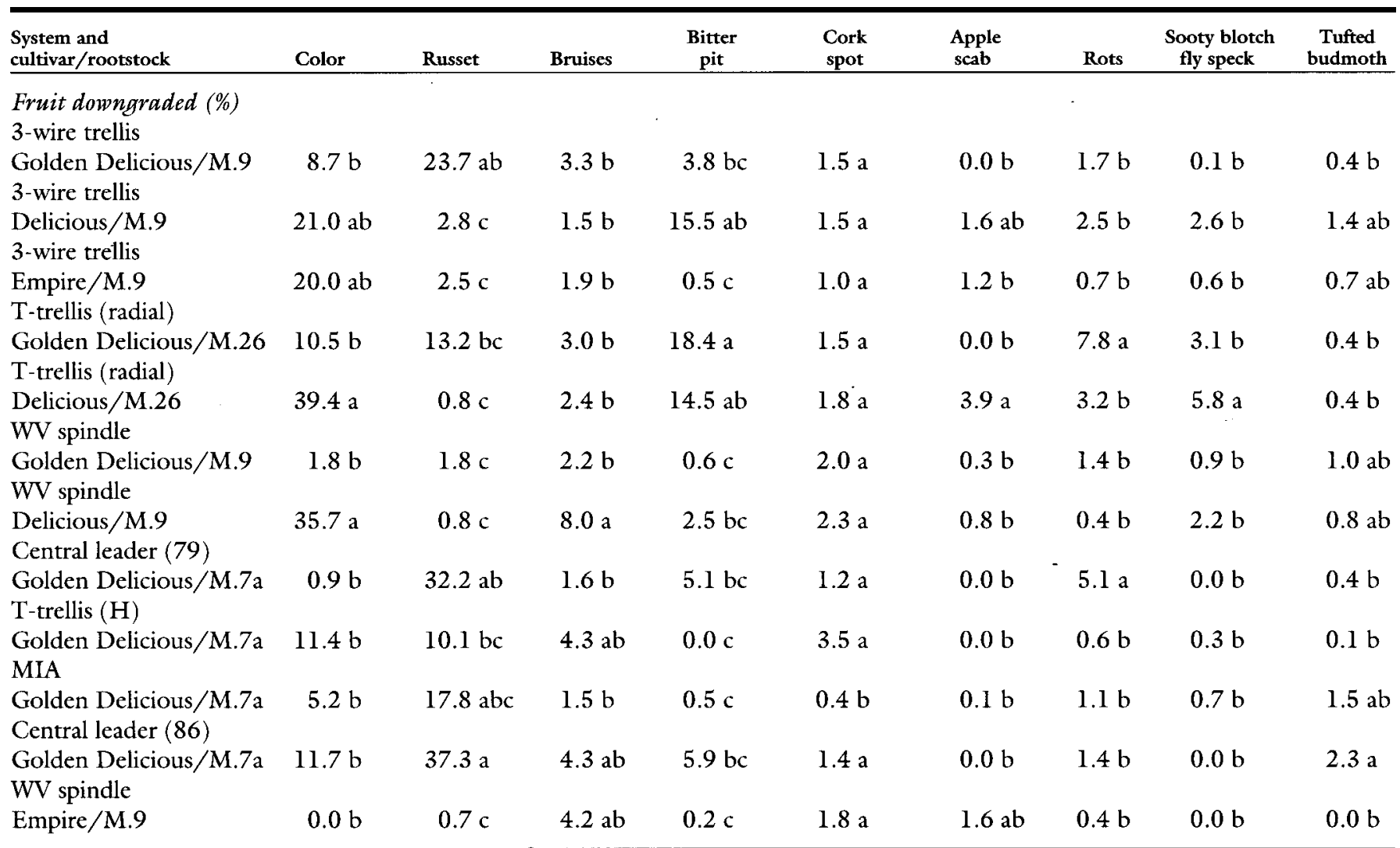

${ }^{2}$ Means within columns followed by the same letter are not significantly different according to $L S D, \mathrm{P} \leq 0.05$.

Table 3. Comparisons of average revenue losses due to defects in five orchard systems during 1991 to 1993.

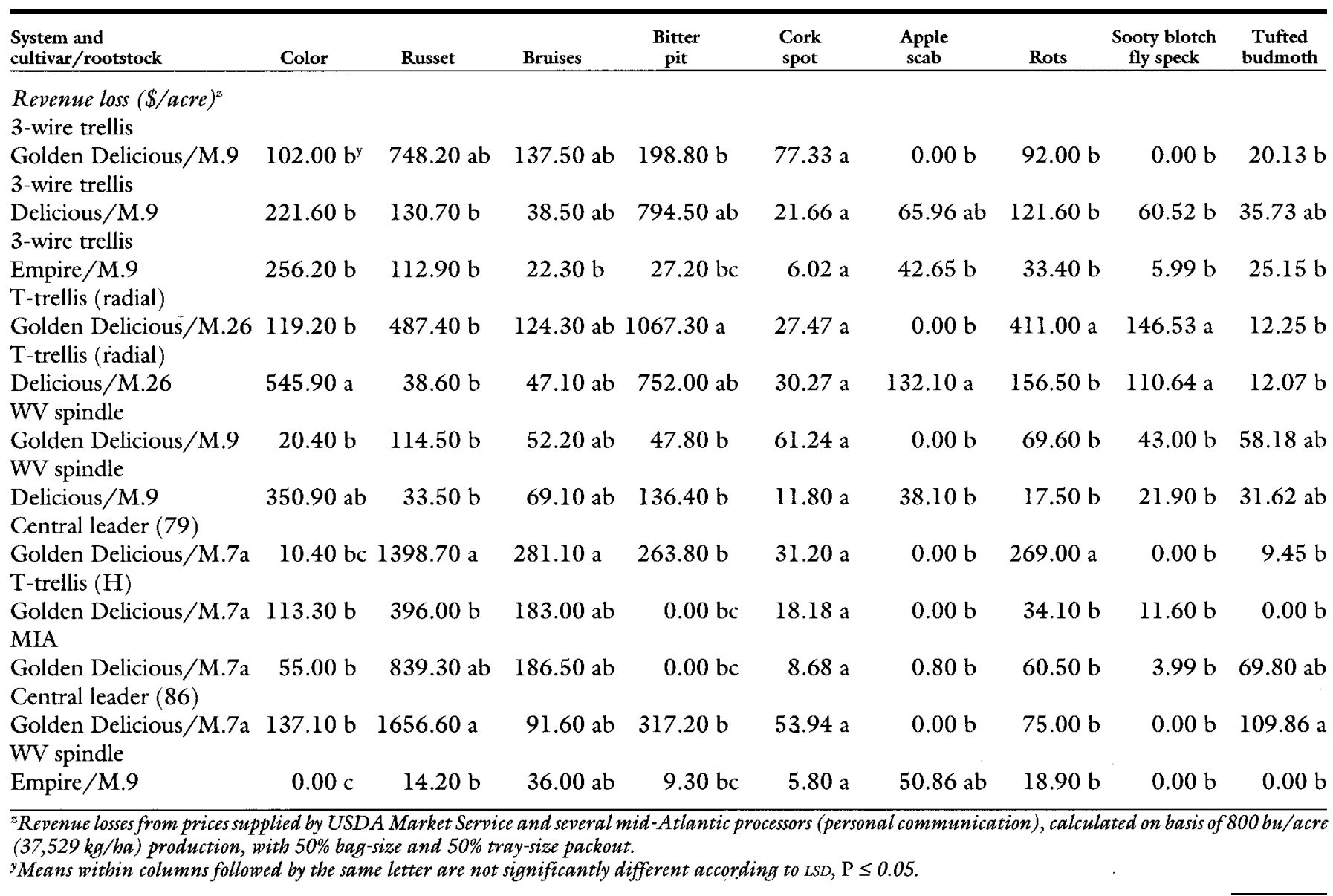



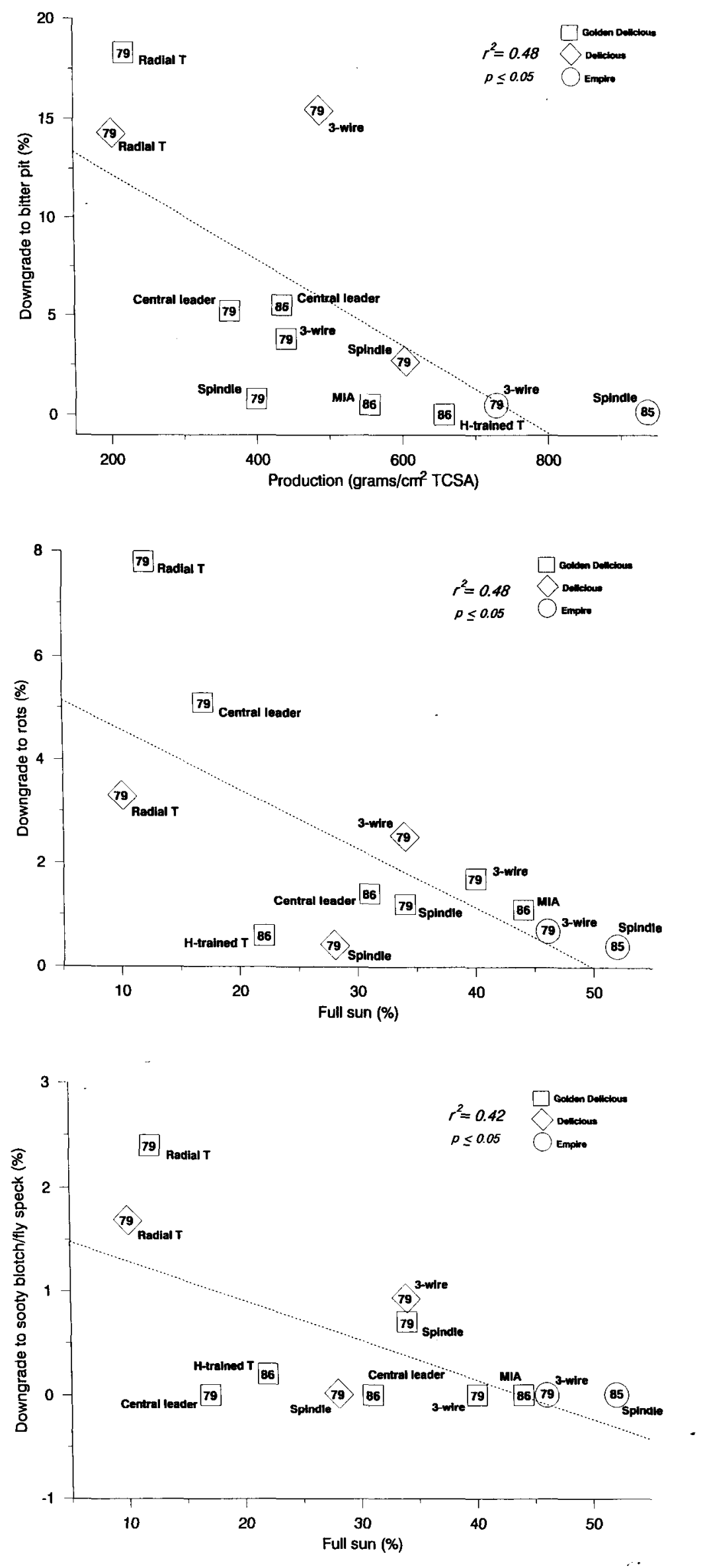

A regression analysis comparing packout below fancy to percent full sun readings indicated that reduced packouts were related $\left(r^{2}=0.40\right)$ to low light conditions (Fig. 2). Other regressions comparing packout to field conditions (e.g., production efficiency, TCSA, tree density) were nonsignificant (data not shown). Previously reported empirical data on the influence of light quality in orchards (Baugher et al., 1994; Ferree et al., 1989b) is supported in this study by the results of a pragmatic grading scheme.

Packout loss factors. Orchard system influenced fruit downgraded due to poor color, russet, bruises, bitter pit, cork spot, apple scab, rots, sooty blotch/fly speck, and tufted apple budmoth (TABM) (Table 2) (Fig. 3). 'Delicious' on 1979 T-trellis (radial) and $1979 \mathrm{WV}$ spindle had the greatest quantity of fruit downgraded due to poor color. 'Golden Delicious' on 1986 central leader exhibited the highest russeting, whereas 'Golden Delicious' on WV spindle and 'Empire' and 'Delicious' on all systems exhibited the least. Ferree (1989) reported that system, level (top or bottom of canopy), and system $\times$ level influenced the incidence of russet on 'Golden Delicious'. 'Delicious' on WV spindle had the greatest percentage of fruit downgraded due to bruises. 'Golden Delicious' on 1979 T-trellis (radial training) had the greatest percentage of fruit with bitter pit, and 'Golden Delicious' on 1986 T-trellis (H), MIA or WV spindle, and 'Empire' on WV spindle or 3-wire trellis had the least. A regression analysis showed that bitter pit decreased as yield efficiency increased $\left(r^{2}=0.48\right)$ (Fig. 3a), presumably due to an improved fruit-to-shoot ratio. Differences in cork spot were minimal, but 'Golden Delicious' on MIA had the lowest incidence.

'Delicious' on 1979 T-trellis (radial) had the greatest percentage of fruit downgraded due to apple scab and sooty blotch/fly speck; 'Golden Delicious' on 1979 T-trellis (radial) or 1979 central leader had the greatest incidence of rots. Regression analyses

Fig. 3. Regressions (significant at $\mathrm{P}$ 0.05) of (top) fruit downgraded due to bitter pit vs production efficiency, (middle) fruit

downgraded due to rots vs percentage of full sun, and (bottom) fruit downgraded due to sooty blotch/fly speck vs percentage of full sun in five orchard systems (1991 to 1993). 
Table 4. Comparison of packout audits for an orchard block with high revenue losses to a block with minimal losses (1992).

\begin{tabular}{|c|c|c|c|c|c|c|c|c|c|c|c|c|c|c|}
\hline \multirow[b]{3}{*}{ Disorder } & \multicolumn{3}{|c|}{ Downgraded to fancy } & \multicolumn{3}{|c|}{ Downgraded to no. 1} & \multicolumn{3}{|c|}{ Downgraded to utility } & \multicolumn{3}{|c|}{ Downgraded to cull } & \multirow{2}{*}{\multicolumn{2}{|c|}{$\begin{array}{c}\text { Total } \\
\text { downgraded }\end{array}$}} \\
\hline & \multirow[b]{2}{*}{$\%$} & \multirow{2}{*}{\multicolumn{2}{|c|}{$\frac{\text { Loss \$/acre }}{(\mathrm{B}-0.50)(\mathrm{T}-2.00)^{2}}$}} & \multirow[b]{2}{*}{$\%$} & \multirow{2}{*}{\multicolumn{2}{|c|}{$\frac{\text { Loss \$/acre }}{(\mathrm{B}-2.00)(\mathrm{T}-5.00)}$}} & \multirow[b]{2}{*}{$\%$} & \multicolumn{2}{|c|}{ Loss \$/acre } & \multirow[b]{2}{*}{$\%$} & \multirow{2}{*}{\multicolumn{2}{|c|}{$\frac{\text { Loss \$/acre }}{(\text { B-5.00) (T-8.00) }}$}} & & \\
\hline & & & & & & & & (B-5.00) & $(T-8.00)$ & & & & $\%$ & $\$ /$ acrey $^{y}$ \\
\hline \multicolumn{15}{|c|}{ Golden Delicious, central leader (86) } \\
\hline Form & --- & -.. & -- & 0.4 & 3.18 & 7.95 & $\cdots$ & --- & --- & --- & --- & $\cdots$ & 0.4 & 11.13 \\
\hline Poor color & 28.0 & 56.06 & 224.26 & 3.0 & 23.86 & 59.65 & $\cdots$ & --- & --- & --- & -- & $\cdots$ & 31.0 & 363.83 \\
\hline Hail &.-- & --- & --- & --- & --- & --- & --- & --- & --- & 4.2 & 83.50 & 133.60 & 4.2 & 217.10 \\
\hline Cracking & 2.6 & 5.17 & 20.67 & 4.4 & 34.99 & 87.47 & --- & $\cdots$ & --- & --- & --- & --- & 7.0 & 148.30 \\
\hline Abrasions & --- & --- & --- & -.. & -- & --- & --- & --- & ... & 1.6 & 31.82 & 50.90 & 1.6 & 82.72 \\
\hline Russeting & --- & --- & --- & 7.4 & 58.85 & 147.12 & 21.9 & 437.38 & 699.81 & --- & --- & --- & 29.3 & 1343.16 \\
\hline Bitter pit & $\ldots$ & $\ldots$ & --- & --- & --- & $\ldots$ & 12.1 & 242.54 & 388.06 & 0.8 & 15.90 & 25.44 & 12.9 & 671.94 \\
\hline Cork spot & 0.2 & 0.40 & 1.58 & --- & -- &.-- & --- & $-:-$ & --- & 0.2 & 3.98 & 6.37 & 0.4 & 12.33 \\
\hline Bruises & --- & $\ldots$ & --- & 2.6 & 20.69 & 51.70 & 3.4 & 67.60 & 108.14 & --- & ... & --- & 6.0 & 248.13 \\
\hline Tufted bu & ..- & -- & --- & --- & $\ldots$ & --- & 1.0 & 19.89 & 31.81 & 2.6 & 51.70 & 82.70 & 3.6 & 186.10 \\
\hline Rots & --- & $\ldots$ & --- & --- & --- &.- & --- & --- & --- & 2.0 & 39.77 & 63.62 & 2.0 & 103.39 \\
\hline \multirow[t]{2}{*}{ Total } & & & & & & & & & & & & & & 3388.13 \\
\hline & $\%$ & (B-0.50) & $(\mathrm{T}-1.50)^{2}$ & $\%$ & (B-1.50) & $(\mathrm{T}-4.50)$ & $\%$ & $(\mathrm{~B}-4.50)$ & $(\mathrm{T}-7.50)$ & $\%$ & $(\mathrm{~B}-\mathbf{4 . 5 0})$ & $(\mathrm{T}-7.50)$ & $\%$ & $\$ /$ acre \\
\hline \multicolumn{15}{|c|}{ Empire, 3-wire trellis } \\
\hline Form & -- &.-- & --- & 0.8 & 4.81 & 14.43 & --- & --- & --- &..- & $\ldots$ & --- & 0.8 & 19.24 \\
\hline Poor color & 3.8 & 7.62 & 22.85 & --- & --- & --- & $\cdots$ & --- & --- & --- & $\cdots$ & --- & 3.8 & 30.47 \\
\hline Hail & --- & -.- & --- & --- & --- & $-\ldots$ & --- & --- & --- & 1.6 & 28.86 & 48.10 & 1.6 & 76.96 \\
\hline Cuts, punctures & --- & --- & --- & -- & --- & --- & --- & -- & $\cdots$ & 0.2 & 3.61 & 6.01 & 0.2 & 9.62 \\
\hline Russeting & --- & --- & --- & 1.0 & 6.01 & 18.04 & 4.4 & 79.35 & 132.26 & --- & --- & --- & 5.4 & 235.66 \\
\hline Bruising & -- & --- & --- & 1.0 & 6.01 & 18.04 & --- & -- & -.. & --- & --- & --- & 1.0 & 24.05 \\
\hline Rots & --- & --- & ... & --- & --- & --- & $\ldots$ & --- & --- & 1.2 & 21.64 & 36.07 & 1.2 & 57.71 \\
\hline Total & & & & & & & & & & & & & & 453.71 \\
\hline
\end{tabular}

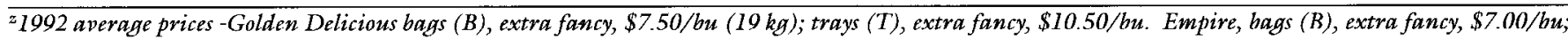
trays (T), extra fancy, $\$ 10.00 /$ bu (from USDA Market Service and several mid-Atlantic processors).

${ }^{y}$ Losses (\$/acre) calculated on basis of $800 \mathrm{bu} /$ acre $(37,529 \mathrm{~kg} / \mathrm{ha})$ production, with $50 \%$ bag-size and $50 \%$ tray-size packout.

indicated that rot and sooty blotch/fly speck incidence were related $\left(r^{2}=\right.$ $0.48, r^{2}=0.42$, respectively) to poor canopy light penetration (Fig. $3 \mathrm{~b}$ and c). 'Golden Delicious' on 1986 central leader had the greatest percentage of fruit downgraded due to TABM. Hogmire and Biggs (1990) reported that differences in fruit damage among these systems generally were greater for diseases than for insects. Byers et al. (1989) determined that the horizontal nature of the T-trellis (radial) canopy prevented effective spray penetration. A noteworthy result from the current study is that pest damage was higher on the central-leader systems than on the medium- to high-density vertical canopy systems in spite of the differences in pesticide rates--full or treerow-volume rates of $50 \%$.

Revenue losses due to defects. Revenue losses were disproportionate to percentage of fruit downgraded, because some defects, e.g., russet, bitter pit, rots and TABM, had a greater impact on grade than others, e.g., color and cork spot (Table 3). This finding is consistent with that from an earlier packout audit conducted in commer- cial packinghouses (Baugher et al., 1990a). The greatest revenue losses (\$/acre) were for russet in 'Golden Delicious' on 1986 central leader (\$1656.60) and for bitter pit on 'Golden Delicious' on 1979 T-trellis (radial) (\$1067.30) (based on constant production and fruit size distribution across systems). 'Delicious' on 1979 T-trellis (radial) had the greatest loss in revenue due to color $(\$ 545.90)$ or apple scab (\$132.10); 'Golden Delicious' on 1979 central leader had the greatest loss due to bruises (\$281.10); 'Golden Delicious' on 1979 T-trellis (radial) or 1979 central leader had the greatest losses due to rots $(\$ 411.00$, $\$ 269.00)$; both cultivars on $1979 \mathrm{~T}$ trellis (radial) had the greatest losses due to sooty blotch/fly speck (\$146.53, \$110.64); and 'Golden Delicious' on 1986 central leader had the greatest loss due to TABM (\$109.86).

Packout audits for individual cultivars/systems provided further illustrations of impacts of fruit defects on returns (Tables 4 and 5). Calculated losses in returns ranged from $\$ 453.71 /$ acre $(\$ 1120.21 / \mathrm{ha})$ for 'Empire' on
3 -wire trellis to $\$ 3388.13$ /acre (\$8365.29/ha) for 'Golden Delicious' on 1986 central leader (1992, Table 4). In these 'Golden Delicious', russet accounted for $\$ 1343.16$ of the total loss in returns. By comparison, poor color downgraded $31 \%$ of the fruit, but the loss was only $\$ 363.83$, because fruit were downgraded only to fancy and no. 1. Hail, abrasions, bitter pit, TABM, and rots downgraded fruit to utility or cull, and, while these defects affected $23.3 \%$ of the fruit, they accounted for $37 \%$ of the total loss. Form, cracking, and cork spot downgraded fruit to fancy and no. 1, affecting $7.8 \%$ of the fruit and accounting for $5.1 \%$ of the revenue loss. Bruises affected $6 \%$ of the fruit and accounted for $7.3 \%$ of the total loss. In 'Empire' on 3-wire trellis, individual disorders affected only $5.4 \%$ of the fruit or less. Only $1.6 \%$ of the fruit was downgraded due to hail, but all were culled for a loss of \$76.96/ acre (\$190.01/ha). Rots also caused fruit to be downgraded to culls. Russeting downgraded $5.4 \%$ of the fruit to no. 1 and utility and accounted for a loss of $\$ 235.66 /$ acre (\$581.84/ha). Cultivar and system were factors in 
Table 5. Comparison of packout audits for same orchard system (Golden Delicious/M.9, radial T) in each of two years (1992 and 1993).

\begin{tabular}{|c|c|c|c|c|c|c|c|c|c|c|c|c|c|c|}
\hline \multirow{3}{*}{ Disorder } & \multicolumn{3}{|c|}{ Downgraded to fancy } & \multicolumn{3}{|c|}{ Downgraded tono. 1} & \multicolumn{3}{|c|}{ Downgraded to utility } & \multicolumn{3}{|c|}{ Downgraded to cull } & \multirow{2}{*}{\multicolumn{2}{|c|}{$\begin{array}{c}\text { Total } \\
\text { downgraded }\end{array}$}} \\
\hline & \multirow[b]{2}{*}{$\%$} & \multicolumn{2}{|c|}{ Loss \$/acre } & \multirow[b]{2}{*}{$\%$} & \multicolumn{2}{|c|}{ Loss $\$$ /acre } & \multirow[b]{2}{*}{$\%$} & \multicolumn{2}{|c|}{ Loss $\$ /$ acre } & \multirow[b]{2}{*}{$\%$} & \multirow{2}{*}{\multicolumn{2}{|c|}{$\frac{\text { Loss } \$ / \text { acre }}{(\mathrm{B}-5.00)(\mathrm{T}-8.00)}$}} & & \\
\hline & & $\overline{(B-0.50)}$ & $(\mathrm{T}-2.00)^{2}$ & & (B-2.00) & $(T-5.00)$ & & (B-5.00) & $(\mathrm{T}-8.00)$ & & & & $\%$ & $\$ /$ acre $^{y}$ \\
\hline \multicolumn{15}{|l|}{1992} \\
\hline Poor color & 17.4 & 34.87 & 139.48 & 1.2 & 9.62 & 24.05 & ... &.-- & --- & -- & $\cdots$ & ... & 18.6 & 208.02 \\
\hline Hail & -- & --- & --- & --- & -.. & -.. & -.- & --- & --- & 2.8 & 56.11 & 89.78 & 2.8 & 145.89 \\
\hline Cuts, punctures & -- & -- & --- & --- & -- & -- & -.- & --- & --- & 1.6 & 32.06 & 51.30 & 1.6 & 83.36 \\
\hline Water core & --- & $-\cdots$ & -.. & -.- & $--\cdot$ & --- & 0.4 & 8.02 & 12.83 & $\cdots$ & $--\cdot$ & --- & 0.4 & 20.85 \\
\hline Russeting & -- & --- & -- & 7.6 & 60.92 & 152.30 & 5.8 & 116.23 & 185.97 & $-\cdots$ & -- & -- & 13.4 & 515.42 \\
\hline Bitter pit & $\cdots$ & $-\cdots$ & --- & --- & --- & $\cdots$ & 7.0 & 140.28 & 224.45 & 10.4 & 208.42 & 333.47 & 17.4 & 906.62 \\
\hline Cork spot & 1.0 & 2.00 & 8.02 & -- & $\ldots$ & $\ldots$ & --- & --- & -- & -.. & -.. &.- & 1.0 & 10.02 \\
\hline Bruises & --- & --- & --- & 2.4 & 19.24 & 48.10 & 1.0 & 20.04 & 32.06 & $-\cdots$ & --- & -- & 3.4 & 119.44 \\
\hline Tufted apple budmoth & --- & -- & -- & --- & --- & --- & 0.2 & 4.01 & 6.41 & $\ldots$ & $\ldots$ & --- & 0.2 & 10.42 \\
\hline Redbanded leafroller & --- & -- & -.- & -.- & -- & $\cdots$ & --- & --- & --- & 0.2 & 4.01 & 6.41 & 0.2 & 10.42 \\
\hline Rots & --- & $\cdots$ & -- & $-\cdot-$ & --- & -- & --- & $\cdots$ & $-\cdots$ & 21.4 & 428.86 & 686.17 & 21.4 & 1115.03 \\
\hline \multirow[t]{2}{*}{ Total } & & & & & & & & & & & & & & 3145.49 \\
\hline & $\%$ & $(\mathrm{~B}-1.00$ & $(\mathrm{T}-2.00)$ & $\%$ & (B-2.50) & $(T-5.50)$ & $\%$ & (B-5.75) & $(\mathrm{T}-8.75)$ & $\%$ & (B-5.75) & (T-8.75) & $\%$ & $\$$ /acre \\
\hline \multicolumn{15}{|l|}{1993} \\
\hline Poor color & 12.5 & 49.90 & 99.80 & --- & $\ldots$ & -.. & -.. & -- & --- &.- & -- & --- & 12.5 & 149.70 \\
\hline Cracks & -- & --- & --- & --- & --- & $\cdots$ & -.. & $-\ldots$ & --- & 0.2 & 4.55 & 6.93 & 0.2 & 11.48 \\
\hline Cuts, punctures & --- & --- & --- &.-- & --- & $\ldots$ & -.- & --- & --- & 2.0 & 45.54 & 69.30 & 2.0 & 114.84 \\
\hline Water core & --- & $-\cdots$ & $-\ldots$ & --- & --- & --- & 5.0 & 113.86 & 173.27 &.- & --- & --- & 5.0 & 287.13 \\
\hline Russeting & -- & -- & $--\cdot$ & 9.3 & 93.07 & 204.75 & 0.6 & 13.66 & 20.79 & -.. & --- & --- & 9.9 & 332.27 \\
\hline Cork spot & $-\ldots$ & -- & --- & --- & -- & -.. & 1.2 & 27.33 & 41.58 & -- & --- & -- & 1.2 & 68.91 \\
\hline Bruises & -- & -. & -.- & 7.9 & 79.21 & 174.26 & --- & --- & -- & $\ldots$ & --- & --- & 7.9 & 253.47 \\
\hline Tufted apple budmoth & 0.2 & 0.79 & 1.58 & --- & --- & $-\cdots$ & --- & $\ldots$ &.-- & 0.2 & 4.55 & 6.93 & 0.4 & 13.85 \\
\hline Tarnished plant bug & -.. & -- & --- & $--\cdot$ & --- & -- & 0.4 & 9.11 & 13.86 & -.. & --- & --- & 0.4 & 22.97 \\
\hline Sooty Blotch & 2.2 & 8.71 & 17.43 & -- & -- & ... & 7.1 & 163.96 & 249.50 & $-\cdots$ & -.. &.- & 9.3 & 439.60 \\
\hline Rots & --- & -- & -.- & $\cdots$ & $\cdots$ & $\cdots$ & --- & --- & --- & 1.4 & 31.88 & 48.51 & 1.4 & 80.39 \\
\hline Total & & & & & & & & & & & & & & 1774.61 \\
\hline
\end{tabular}

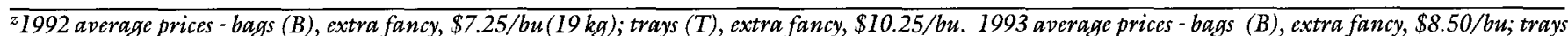
(T), extra fancy, $\$ 11.50 /$ bu (from USDA Market Service and several mid-Atlantic processors).

${ }^{y}$ Losses (\$/acre) calculated on basis of $800 \mathrm{bu} /$ acre $(37,529 \mathrm{~kg} / \mathrm{ha})$ production, with $50 \%$ bag-size and $50 \%$ tray-size packout.

minimizing losses. 'Golden Delicious' on 3-wire trellis had $31 \%$ lower total losses than 'Golden Delicious' on central leader (data not shown). The 3wire trellis was associated with improvements in color, finish, and calcium-related disorders (cork spot, bitter pit). 'Empire' on 3-wire trellis had an additional $56 \%$ reduction in total losses compared to 'Golden Delicious' on 3-wire trellis.

Losses per bushel $(19 \mathrm{~kg} / \mathrm{bu})$ were higher in 1993 due to higher prices; however, 1992 revenue losses in 'Golden Delicious' on 1979 T-trellis (radial) were almost double those in 1993 (Table 5). Factors affected primarily by management, e.g., bruises, cuts and punctures, were similar in both years. Defects affected by weather, e.g., poor color, hail, russeting, bitter pit, and rots, caused $73.6 \%$ of the fruit to be downgraded in 1992 compared to $23.8 \%$ in 1993 , with corresponding losses of $\$ 2890.98 /$ acre (\$7137.83/ ha) and $\$ 562.36 /$ acre (\$1388.47/ ha). Although percentage of rots and redbanded leafroller (RBLR) decreased in 1992, TABM, tarnished plant bug (TPB), and sooty blotch/fly speck increased. Fewer sprays were applied in 1993 than in 1992, and the lower spray deposit (Byers et al., 1989) in this horizontal canopy system resulted in greater pest problems.

Implications for growers. The packout audits and comparisons to field data provide useful information for growers to use in selecting an orchard system. The data provide further support for planting newer systems with higher light levels. The comparisons of yields and packouts of young and mature systems indicate that vertical or inclined canopy systems of 363 or more trees per acre (896 trees per ha) are superior to horizontal canopy or low-density vertical freestanding sys- tems. This finding is consistent with internal rate of return analyses conducted by Funt et al. (1992).

Perhaps of equal use to growers are the implications related to management of different systems. The costbenefit analyses prescribe areas where changes can be made in existing systems to increase profitability. For example, packout audits comparing the radial training of the $\mathrm{T}$-trellis to the newer H-training program imply that light and spray penetration can be improved through modifications in pruning. Packout audits provide clues to improved management of specific cultivar/rootstock combinations on specific training systems grown in distinctive microclimates. We propose that this total system approach to growing apples more intensively will help growers compete successfully in an increasingly competitive industry environment. 


\section{Literature Cited}

Baugher, T.A., H.W. Hogmire, and G.W. Lightner. 1990a. Determining apple packout losses and impact on profitability. Applied Agr. Res. 5(4):343-349.

Baugher, T.A., S.H. Blizzard, S. Singha, K.C. Elliott, and D.W. Leach. 1990b. Intensive orcharding, a total system approach-Lincoln canopy. WVU Ext. Publ. O M 8

Baugher, T.A., S.H. Blizzard, and S. Singha. 1990c. Intensive orcharding, a total system approach-MIA trellis. WVU Ext. Publ. OM10.

Baugher, T.A., S. Singha, and D.W. Leach. 1990d. Intensive orcharding, a total system approach-WV spindle. WVU Ext. Publ. OM13.

Baugher, T.A., H.W. Hogmire, G.W. Lightner, S.I. Walter, and D.W. Leach. 1990e. Determining apple packout losses and impact on profitability. WVU Ext. Publ. OM105.

Baugher, T.A., S. Singha, D.W. Leach, and S.P. Walter. 1994. Growth, productivity, spur quality, light transmission and net photosynthesis of 'Golden Delicious' apple trees on four rootstock in three training systems. Fruit Var. J. 48(4):251-255.

Blizzard, S.H., S. Singha, T.A. Baugher, and B.D. Cayton. 1988. Yield and fruit quality of apple trees under three high density management systems. Fruit Var. J. 42(2):67-72.

Byers, R.E., H.W. Hogmire, D.C. Ferree, F.R. Hall, and S.J. Donahue. 1989. Spray chemical deposits in high-density and trellis apple orchards. HortScience 24:918920.

Elliott, K.C. and A.W. Selders. 1990. Intensive orcharding, a total system approach -Basic trellis construction. WVU Ext. Publ. OM14.

Ferree, D.C. 1989. Influence of orchard management systems on spur quality, light, and fruit within the canopy of 'Golden Delicious' apple trees. J. Amer. Soc. Hort. Sci. 114:869-875.

Ferree, D.C., R.C. Funt, and B.L. Bishop. 1989a. Yield and production efficiency of four apple cultivars in selected orchard management systems. J. Amer. Soc. Hort. Sci. 114:863-868.
Ferree, D.C., J.R. Schupp, S.H. Blizzard, T.A. Baugher, and I.J. Warrington. 1989b. Influence of five orchard management systems on canopy composition, light penetration and net photosynthesis of 'Golden Delicious' apple. Acta Hort. 243:131-140.

Ferree, D.C. 1994. Early performance of two apple cultivars in three training systems. HortScience 29:1004-1007.

Funt, R.C., T.A. Baugher, H.W. Hogmire, and W.C. Kleiner. 1992. Profitability of different apple orchard systems in the Eastern United States. OSU Hort. Dept. Ser. 624.

Hogmire, H.W., T.A. Baugher, M. Ingle, and G.W. Lightner. 1989. Development of a sampling plan and application of a grading scheme for determining apple packout losses. HortScience 24:628-630.

Hogmire, H.W. and A.R. Biggs. 1990. Pest management in intensive apple systems. Proc. Regional Ext. Fruit School, Middleway, W.Va.

Hogmire, H.W. and R.E. Byers. 1990. Intensive orcharding, a total system appreach-Spray chemical deposits in high density and trellis apple orchards. WVU Ext. Publ. OM12.

Robinson, T.L., A.N. Lakso, and S.G. Carpenter. 1991. Canopy development, yield, and fruit quality of 'Empire' and 'Delicious' apple trees grown in four orchard production systems for ten years. J. Amer. Soc. Hort. Sci. 116:179-187.

Russo, J.M. and E.G. Rajotte. 1983. A theoretical grading scheme for production decision making: an application to fresh market apples. PSU College of Agr. Bul. 844.

Singha, S., T.A. Baugher, and S.H. Blizzard. 1990. Intensive orcharding, a total system approach-3-wire trellis. WVU Ext. Publ. OM7.

Snedecor, G.W. and W.G. Cochran. 1968. Statistical methods. 6th ed. Iowa State Univ. Press, Ames.

Virginia and West Virginia Cooperative Extension Services. 1993. 1993 Spray bulletin for commercial tree fruit growers. VPI Publ. 456-419.

Zimmerman, R.K., T.A. Baugher, and S. Singha. 1990. Pruning and training fruit trees. WVU Ext. Publ. OM106. 